\title{
OPEN New cassava germplasm for food and nutritional security in Central Africa
}

\author{
Isaac Tize ${ }^{1,2}$, Apollin Kuate Fotso ${ }^{1 凶}$, Elias Nchiwan Nukenine ${ }^{2}$, Cargele Masso ${ }^{1}$, \\ Francis Ajebesone $\mathrm{Ngome}^{3}$, Christopher Suh ${ }^{3}$, Venasius Wirnkar Lendzemo ${ }^{3}$, \\ Ibrahim Nchoutnji ${ }^{3}$, Gabriel Manga ${ }^{3}$, Elisabeth Parkes ${ }^{4}$, Peter Kulakow ${ }^{4}$, Christiant Kouebou ${ }^{5}$, \\ Komi K. M. Fiaboe ${ }^{1}$ \& Rachid Hanna ${ }^{1,6}$
}

Cassava is a key food security crop in Central Africa, but its production depends largely on the use of local farmers' varieties characterized by inherently low yield which is compounded by generally high susceptibility to various growth and yield-limiting pests and diseases. Improved cassava genotypes have demonstrated the potential to substantially improve cassava's contribution to food security and the development of the cassava industry and the improvement of nutrition status elsewhere in Western Africa. Eleven improved cassava genotypes were compared with a local landrace (LMR) used as a check under field conditions over two years in eight locations, grouped in four agro-ecologies in Cameroon. Pest and disease abundance/incidence and damage severity were evaluated. At harvest, root yield and carotenoid content were measured. Best linear unbiased predictors showed the lowest breeding value for LMR with the cassava mosaic virus disease $(+66.40 \pm 2.42)$ compared with $1.00 \pm 0.02 \%$ for the most susceptible improved genotype. Two genotypes (1010040-27 and 1011797 ) stood out for having higher predicted fresh root yield means which were at least 16 times greater compared with LMR. Predicted total carotenoid content was the highest $(+5.04 \pm 0.17)$ for improved genotype 1070593 compared with LMR which showed the lowest $(-3.90 \pm 0.06 \%)$ and could contribute to the alleviation of vitamin A deficiency from cassava-based food systems. Diffusion of high-yielding and nutritious genotypes could alleviate food and nutritional security in Central Africa.

Cassava (Manihot esculenta Crantz), is the main source of calories for 800 million people across the globe ${ }^{1}$. No other continent depends on cassava to feed as many people as does Africa ${ }^{2}$. Its production is estimated at 178 million tons-61\% of global production-produced annually in sub-Saharan Africa (SSA) ${ }^{3}$. Population growth and demands by emerging cassava industries are increasingly straining current production capacities that rely widely on low-yielding farmers' local varieties that are particularly susceptible to widespread and emerging pests and diseases such as cassava mosaic virus disease, cassava brown streak virus disease, and cassava whiteflies ${ }^{4-8}$. Moreover, the local varieties are deficient in micronutrients, thus their consumption could lead to micronutrient deficiency, also referred to as hidden hunger ${ }^{9}$. Acute deficiencies in one or more micronutrients, including vitamins A, C, E, and minerals are reported in about two billion people ${ }^{9}$. In Cameroon, about $39 \%$ of preschool-aged children and $18 \%$ of pregnant women are deficient in vitamin A. For example, acute malnutrition is estimated at around $4.8 \%$ in the East region of Cameroon ${ }^{10}$. According to UNHCR (2018), nearly 265,000 refugees from the Central African Republic have sought shelter in eastern Cameroon, increasing the level of food insecurity in the region.

Aiming at improving the production of cassava on the continent, the International Institute of Tropical Agriculture (IITA) and its partners have developed new cassava genotypes to improve the livelihoods of millions of farmers in SSA. It is now widely recognized that traditional staple crops (rice, wheat, maize, and soybean) are no longer providing adequate and enough solutions to the world's food insecurity ${ }^{11-14}$. Cassava in this regard is recognized as a crop that can contribute to global food security ${ }^{12,15-18}$.

\footnotetext{
${ }^{1}$ International Institute of Tropical Agriculture, BP 2008, Messa, Yaoundé, Cameroon. ${ }^{2}$ Department of Biological Sciences, University of Ngaoundere, BP 454, Ngaoundere, Cameroon. ${ }^{3}$ Institute of Agricultural Research for Development, BP 2067, Yaoundé, Cameroon. ' International Institute of Tropical Agriculture, PMB 320 Oyo Road, Ibadan, Nigeria. ${ }^{5}$ Agricultural Investment and Market Development Project, Yaoundé, Cameroon. ${ }^{6}$ Present address: Congo Basin Institute, Institute of Environment and Sustainability, University of California, Box 951496, Los Angeles, USA. ${ }^{\varpi}$ email: a.fotso@cgiar.org
} 


\begin{tabular}{|c|c|c|c|c|c|c|c|c|c|c|}
\hline \multirow[b]{2}{*}{ Locations } & \multirow{2}{*}{$\begin{array}{l}\mathrm{pH} \\
\text { Water }\end{array}$} & $\mathrm{Ca}$ & $\mathrm{Mg}$ & $\mathbf{K}$ & \multirow{2}{*}{$\begin{array}{l}P \\
u g / g\end{array}$} & Org C & Total N & Sand & Clay & Silt \\
\hline & & \multicolumn{3}{|l|}{$\operatorname{cmol}(+) / \mathrm{kg}$} & & \multicolumn{5}{|l|}{$\%$} \\
\hline Bambui & $3.93 \pm 0.01^{\mathrm{d}}$ & $0.97 \pm 0.05^{f}$ & $0.37 \pm 0.02^{f}$ & $0.26 \pm 0.01^{\mathrm{d}}$ & $2.44 \pm 0.05^{\mathrm{d}}$ & $6.96 \pm 0.03^{\mathrm{a}}$ & $0.44 \pm 0.00^{\mathrm{a}}$ & $54.2 \pm 0.39^{c}$ & $18.3 \pm 0.36^{\mathrm{e}}$ & $27.5 \pm 0.14^{\mathrm{a}}$ \\
\hline Gamboula & $4.11 \pm 0.03^{\mathrm{d}}$ & $1.21 \pm 0.08^{\mathrm{ef}}$ & $0.74 \pm 0.04^{\mathrm{e}}$ & $0.14 \pm 0.00^{\mathrm{d}}$ & $8.10 \pm 0.4^{\mathrm{d}}$ & $2.32 \pm 0.04^{\mathrm{e}}$ & $0.14 \pm 0.00^{\mathrm{fg}}$ & $54.3 \pm 0.41^{\mathrm{c}}$ & $36.6 \pm 0.45^{\mathrm{b}}$ & $9.17 \pm 0.25^{\mathrm{e}}$ \\
\hline Ekona & $4.91 \pm 0.05^{\mathrm{bc}}$ & $9.64 \pm 0.23^{c}$ & $3.94 \pm 0.08^{\mathrm{b}}$ & $1.77 \pm 0.07^{\mathrm{a}}$ & $61.3 \pm 2.67^{\mathrm{a}}$ & $3.50 \pm 0.04^{\mathrm{d}}$ & $0.35 \pm 0.00^{c}$ & $48.6 \pm 0.69^{\mathrm{d}}$ & $27.3 \pm 0.54^{\mathrm{c}}$ & $24.1 \pm 0.41^{\mathrm{c}}$ \\
\hline Foumbot & $6.06 \pm 0.02^{\mathrm{a}}$ & $15.4 \pm 0.18^{\mathrm{a}}$ & $5.21 \pm 0.12^{\mathrm{a}}$ & $1.54 \pm 0.05^{\mathrm{b}}$ & $20.9 \pm 0.7^{\mathrm{bc}}$ & $5.74 \pm 0.03^{\mathrm{b}}$ & $0.40 \pm 0.01^{\mathrm{b}}$ & $63.6 \pm 0.36^{\mathrm{b}}$ & $11.2 \pm 0.34 \mathrm{f}$ & $25.2 \pm 0.23^{\mathrm{b}}$ \\
\hline Mbalmayo & $4.70 \pm 0.05^{\mathrm{c}}$ & $3.01 \pm 0.21^{\mathrm{def}}$ & $1.27 \pm 0.07^{\mathrm{d}}$ & $0.16 \pm 0.01^{\mathrm{d}}$ & $10.1 \pm 1.7^{\mathrm{cd}}$ & $1.73 \pm 0.2 \mathrm{f}$ & $0.15 \pm 0.00 \mathrm{f}$ & $61.30 \pm 0.85^{\mathrm{b}}$ & $26.0 \pm 0.80^{\mathrm{cd}}$ & $12.7 \pm 0.22^{\mathrm{d}}$ \\
\hline Meiganga & $5.32 \pm 0.08^{\mathrm{b}}$ & $11.9 \pm 1.07^{\mathrm{b}}$ & $2.51 \pm 0.06^{\mathrm{c}}$ & $0.55 \pm 0.02^{\mathrm{c}}$ & $71.4 \pm 6.6^{\mathrm{a}}$ & $5.15 \pm 0.05^{c}$ & $0.30 \pm 0.00^{\mathrm{d}}$ & $53.9 \pm 0.68^{c}$ & $23.5 \pm 0.41^{\mathrm{d}}$ & $22.7 \pm 0.37^{\mathrm{bc}}$ \\
\hline Meyomessala & $4.84 \pm 0.04^{\mathrm{c}}$ & $3.77 \pm 0.57^{\mathrm{d}}$ & $0.90 \pm 0.11^{\mathrm{e}}$ & $0.18 \pm 0.02^{\mathrm{d}}$ & $29.2 \pm 2.3^{\mathrm{b}}$ & $1.65 \pm 0.05 f$ & $0.12 \pm 0.00^{\mathrm{g}}$ & $81.7 \pm 0.53^{\mathrm{a}}$ & $12.1 \pm 0.42^{\mathrm{f}}$ & $6.23 \pm 0.24^{f}$ \\
\hline Njombe & $3.93 \pm 0.06^{\mathrm{d}}$ & $2.50 \pm 0.33^{\mathrm{de}}$ & $0.88 \pm 0.10^{\mathrm{de}}$ & $0.19 \pm 0.03^{\mathrm{d}}$ & $8.75 \pm 1.7^{\mathrm{cd}}$ & $2.33 \pm 0.15^{\mathrm{e}}$ & $0.18 \pm 0.01^{\mathrm{e}}$ & $45.6 \pm 2.23^{\mathrm{d}}$ & $43.7 \pm 2.90^{\mathrm{a}}$ & $10.6 \pm 1.41^{\mathrm{e}}$ \\
\hline Mean & 4.72 & 6.06 & 1.98 & 0.60 & 26.5 & 3.67 & 0.26 & 57.9 & 24.8 & 17.3 \\
\hline SE & 0.26 & 1.94 & 0.62 & 0.24 & 9.23 & 0.72 & 0.05 & 3.99 & 4.00 & 2.98 \\
\hline $\mathrm{CV}$ & 15.6 & 90.8 & 88.7 & 111.4 & 98.4 & 55.3 & 49.7 & 19.5 & 45.6 & 48.8 \\
\hline
\end{tabular}

Table 1. Average soil physical and chemical characteristics $( \pm S E)$. Means in a column followed by the same letter are not significantly different. $S E$ standard error, $C V$ coefficient of variation.

Cassava is resistant to adverse environments ${ }^{19}$; however, its production in Cameroon and elsewhere-particularly in Central Africa-is constrained by heavy yield losses from pests and diseases among which are: (1) cassava mosaic virus disease (CMD) transmitted largely by the whitefly Bemisia tabaci (G.) and by infected cassava stems used as vegetative propagules; (2) cassava anthracnose disease (CAD) caused by the fungus Colletotrichum gloeosporioides (Penz.) Sacc. and also vectored by Pseudotheraptus devastans Dist. (Het. Coreidae); and (3) cassava green mite (CGM) Mononychellus tanajoa (B. $)^{20-23}$. CMD is the most challenging disease as it can cause $25-90 \%$ yield losses, with substantial negative impact on people's livelihoods $s^{5,6,24}$, particularly where CMD-susceptible traditional farmers cassava varieties are used compared with the CMD-resistant improved varieties ${ }^{4,8}$. Host plant resistance provides the cheapest and simplest technology where chemical inputs are not available or affordable.

Crop improvement has traditionally focused on increasing crop yield and building resistance to pests and diseases. In recent years, enhancement of crops nutrient has been increasingly incorporated in breeding programs. Biofortification of staple food crops like cassava has been advocated as one of the cost-effective solutions to combat the scourge of micronutrient malnutrition ${ }^{25}$ and for sustainable improvement in the lives of millions of people in developing countries, particularly in Africa and South Asia ${ }^{25-27}$.

Genotype $\mathrm{x}$ environment interaction is the greatest challenge to breeders due to differential genotypic responses across environments ${ }^{15,28-32}$. In a previous study ${ }^{8}$, we evaluated a set of 18 cassava genotypes, mostly oriented toward industrial processing, across eight environments in Cameroon to assess the level of stability of their yield and pest and disease resistance. The principal objective of the present study was to evaluate and select new cassava genotypes suitable for non-fermented products prepared using a single-step process after peeling (boiling or frying) and with high resistance to CMD and other pests, and with higher provitamin A content under specific environments. Broadly, the results from this Cameroon study are likely to be extended to countries sharing similar ecologies, mainly in the Congo Basin, as Cameroon, with its varied environments, is considered the gateway to the rest of Central Africa.

\section{Results}

Soil nutrient analysis. The levels of soil $\mathrm{pH}$ and various soil chemical characteristics varied among locations. Soil $\mathrm{pH}$ in Foumbot (6.06 \pm 0.02$)$ differed significantly from the other locations, with Bambui and Njombe being most acidic $(3.93 \pm 0.01$ and $3.93 \pm 0.06$ respectively). The highest organic carbon content $(6.96 \pm 0.03)$ was recorded in Bambui. Ekona, Foumbot, and Meiganga differed from the other locations with their higher level of $\mathrm{Ca}, \mathrm{Mg}$, and P. Meyomessala soil had the highest sand content while Njombe and Bambui soils had the highest clay and silt respectively (Table 1).

Best linear unbiased predictors (BLUPs) for the diseases: CMD and CAD. The predicted breeding values of CMD ranged from $-7.79 \pm 2.42$ for genotype I090521, which did not show any disease symptoms, to $+66.40 \pm 2.42$ for the local landrace LMR, which had the highest CMD incidence and severity $(+1.36 \pm 0.10)$ (Table 2). The most infected improved variety was I010040-27 with a BLUP of $+1.00 \pm 0.02 \%$. Other genotypes performed below the grand mean and with a very small difference among them (Fig. 1A).

The quadrants in Fig. 2 represent the four classes of cassava genotypes/location for a joint interpretation of CMD performance and stability, using the weighted average of absolute scores for the BLUP of the genotypes and location interaction (WAABS) in the eight locations. The 1st quadrant shows that no genotype contributed much to the genotype and location interaction, but there were 2 locations-Foumbot and Meyomessala-that displayed a high discriminative ability for CMD. The 2nd quadrant includes two genotypes, I010040-27 and LMR, which were the most infected and unstable. The two locations included on that quadrant (Gamboula and Njombe), in addition to high disease incidence, also had good discrimination ability for the genotypes. Ten genotypes fell in the $3 \mathrm{rd}$ quadrant and are considered as low-infection genotypes, because of the low WAABS values for CMD. No location was included in 3rd quadrant, which was the environment with low infection and 


\begin{tabular}{|c|c|c|c|c|c|c|}
\hline Genotype/statistics & CMD incidence & CMD severity & CAD incidence & CAD severity & WF & CGM \\
\hline I010040-27 & $+1.00 \pm 0.02$ & $+0.24 \pm 0.25$ & $+0.50 \pm 3.61$ & $+0.06 \pm 0.01$ & $-7.30 \pm 7.39$ & $+1.26 \pm 4.79$ \\
\hline I070557 & $-7.72 \pm 2.42$ & $-0.23 \pm 0.27$ & $-4.43 \pm 2.61$ & $-0.07 \pm 0.15$ & $+9.13 \pm 5.32^{*}$ & $-0.25 \pm 3.45$ \\
\hline I011797 & $-7.28 \pm 19.8$ & $-0.18 \pm 1.44$ & $-1.12 \pm 2.48$ & $+0.01 \pm 0.00$ & $-2.28 \pm 6.67$ & $-2.28 \pm 4.33$ \\
\hline I090590 & $-2.17 \pm 2.42$ & $+0.11 \pm 0.16$ & $-2.71 \pm 3.61$ & $+0.00 \pm 0.00$ & $-7.6 \pm 6.58$ & $-0.73 \pm 4.27$ \\
\hline I090537 & $-7.23 \pm 2.42$ & $-0.07 \pm 0.38$ & $+0.71 \pm 3.61$ & $+0.03 \pm 0.08$ & $-2.74 \pm 5.62$ & $-0.94 \pm 3.64$ \\
\hline I070738 & $-7.72 \pm 2.42$ & $-0.22 \pm 0.42^{*}$ & $-1.62 \pm 3.61$ & $-0.03 \pm 0.10$ & $-7.18 \pm 6.53$ & $-2.85 \pm 4.23$ \\
\hline I090574 & $-6.67 \pm 2.42$ & $-0.09 \pm 0.60$ & $+3.03 \pm 2.61$ & $+0.03 \pm 0.0$ & $+9.68 \pm 5.28$ & $4.75 \pm 3.42$ \\
\hline I090616 & $-7.53 \pm 0.83^{\star *}$ & $-0.19 \pm 0.23^{\star}$ & $+2.07 \pm 1.23$ & $+0.05 \pm 0.08^{*}$ & $+6.36 \pm 5.77$ & $+8.51 \pm 3.74^{*}$ \\
\hline I090521 & $-7.79 \pm 2.42$ & $-0.26 \pm 0.01$ & $+0.16 \pm 3.61$ & $+0.03 \pm 0.08$ & $+19.6 \pm 5.04^{* *}$ & $-1.10 \pm 3.26$ \\
\hline I070593 & $-5.90 \pm 2.42$ & $-0.18 \pm 0.36$ & $-2.57 \pm 3.61$ & $-0.03 \pm 0.10$ & $-6.60 \pm 5.67$ & $-1.68 \pm 3.67$ \\
\hline I071026 & $-7.36 \pm 0.00$ & $-0.23 \pm 0.27$ & $-2.52 \pm 3.61$ & $-0.07 \pm 0.15$ & $-9.06 \pm 0.06$ & $-3.73 \pm 4.80$ \\
\hline LMR & $+66.4 \pm 2.42$ & $+1.36 \pm 0.10$ & $+4.90 \pm 3.21$ & $+0.07 \pm 0.01$ & $-1.95 \pm 2.77$ & $-0.94 \pm 2.15$ \\
\hline Heritability $\left(\mathrm{H}^{2}\right)$ & 0.90 & 0.64 & 0.08 & 0.08 & 0.04 & 0.01 \\
\hline Location variance $(\mathrm{L})$ & 74.22 & 16.12 & 15.48 & 146.7 & 28.5 & 5.80 \\
\hline Genotype variance $(\mathrm{G})$ & $473^{* *}$ & $0.33^{\star *}$ & 149 & 0.02 & 70.0 & 92.0 \\
\hline $\mathrm{G} \times \mathrm{L}$ variance & $35,106^{\star *}$ & $5.32^{\star}$ & $2244.6^{* *}$ & 0.00 & 2347 & 533.6 \\
\hline Residual variance & 59.20 & 4.77 & 145.7 & 3.72 & 1997.2 & 882.46 \\
\hline Grand mean & 7.70 & 1.27 & 7.64 & 1.17 & 26.53 & 10.32 \\
\hline SE & 0.9 & 0.03 & 0.7 & 0.02 & 0.61 & 0.37 \\
\hline Minimum & -8.46 & -0.26 & -4.43 & -0.07 & -9.06 & -3.73 \\
\hline Maximum & 65.6 & 1.36 & 4.90 & 0.05 & 19.60 & 8.51 \\
\hline SD & 21.38 & 0.58 & 16.47 & 0.42 & 51.7 & 31.33 \\
\hline CV (\%) & 278.1 & 45.8 & 215.8 & 35.73 & 194.9 & 303.7 \\
\hline n Replicates & 3 & 3 & 3 & 3 & 3 & 3 \\
\hline $\mathrm{n}$ Locations & 8 & 8 & 8 & 8 & 8 & 8 \\
\hline n Genotypes & 12 & 12 & 12 & 12 & 12 & 12 \\
\hline
\end{tabular}

Table 2. Best linear unbiased predictors (BLUPs) of breeding values with standard errors for cassava mosaic disease (CMD) incidence (\%) and severity, cassava anthracnose disease (CAD) incidence (\%), and densities of, whiteflies (WF), cassava green mite (CGM). ${ }^{\star} P<0.05$, ${ }^{*} P<0.01$. The statistics listed for every trait are broadsense heritability, genotype variance, residual variance, grand mean, $\mathrm{SD}=$ Standard Deviation, the coefficient of variation (CV \%), the number of replications (n Replicates), and the number of genotypes (n Genotypes). The statistics shown are the estimates derived.

discrimination ability. There were no broadly adapted genotypes to be displayed in the 4th quadrant; however, there were 2 locations (Ekona and Meiganga) that had high CMD incidence but with low discriminative ability.

For CAD, the BLUP breeding values ranged from $-4.43 \pm 2.61$ for improved genotypes (I070557), which showed the lowest CAD incidence,- to $+4.90 \pm 3.21$ for LMR which also had the highest CAD severity $(+0.07 \pm 0.01)$ (Table 2). Six genotypes had CAD incidence above the grand mean, but the predicted disease incidence was below $15 \%$ for all genotypes (Fig. 1B).

Results from all genomic predictions showed higher heritability for CMD incidence (0.90) and severity $(0.64)$ compared with CAD. The linear mixed model test indicated highly significant effects $(p<0.001)$ in genotype $\mathrm{x}$ environment interactions for all the parameters (Table 2).

Best linear unbiased predictors (BLUPs) for the pests: WF and CGM. The predicted values for whiteflies ranged from $-9.06 \pm 0.06$ on genotype I071026 to $+19.60 \pm 5.04$ on I090521, which had the highest number of individuals per plant. The highest BLUP for CGM $(+8.51 \pm 3.74)$ was predicted on I090616, while the lowest was on I071026 (-3.73 \pm 4.80$)$ (Table 2).

BLUP for fresh root yields, biomass, dry matter, and total carotenoids content (TCC). Two genotypes (I010040-27 and I011797) stood out for having the highest predicted fresh root yield means among all the tested genotypes (Table 3). The yields of genotypes I090590 and I0701026 were also above the grand mean (Fig. 3B). The predicted breeding values for fresh root yield ranged from $-12.2 \pm 2.23$ for genotype I070557, which showed the lowest root yield, to $+13.5 \pm 1.89$ for genotype I010040-27, which had the highest root yield. For cassava above-ground biomass, which included stems and leaves, the predicted breeding values ranged from $-3.73 \pm 1.62$ for genotype I071026, which showed the lowest value, to $+8.51 \pm 1.57$ for genotype I090616, which had the highest aboveground biomass. The biomass of five genotypes was above the grand mean (Fig. 3A) The predicted breeding values for dry matter ranged from $-4.03 \pm 0.02$ for genotype I070593, which showed the lowest DM content, to $+9.36 \pm 3.03$ for the local landrace LMR, which had the highest DM content (Table 3 ). Pre- 

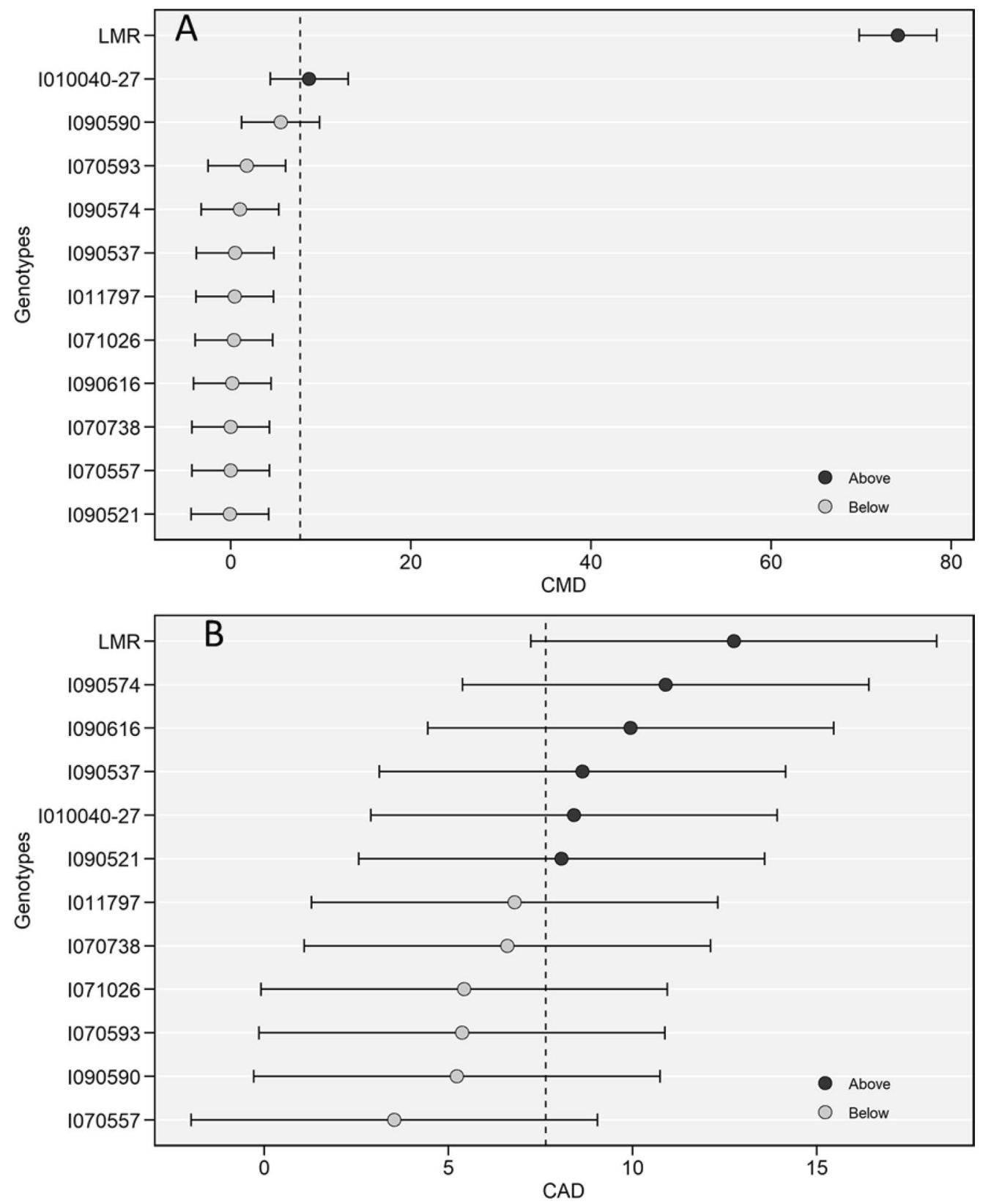

Figure 1. Best linear unbiased prediction of $\mathrm{CMD}(\mathbf{A})$ and $\mathrm{CAD}(\mathbf{B})$ incidence (\%) for 12 cassava genotypes. Black and grey circles represent the genotypes that had BLUP above and below of BLUP mean, respectively. Horizontal error bars represent the $95 \%$ confidence interval of a prediction considering a 2 -tailed $t$ test. (R V3.6.2, https://cran.r-project.org/web/packages/metan/).

dicted total carotenoid content (TCC) was the highest $(+5.04 \pm 0.17)$ for improved genotype I070593 compared with LMR, which showed the lowest $(-3.90 \pm 0.06 \%)$ (Table 3).

Overall, the highest heritability (0.60) among the traits was estimated from TCC (Table 3$)$. The linear mixed model indicated highly significant effects $(p<0.001)$ for genotype and environmental interactions for all tested traits (Table 3 ).

The quadrants in Fig. 4 represent the 4 classes of cassava genotypes/location for a joint interpretation of fresh root yield and stability using the weighted average of absolute scores for the BLUP of the genotype and location interaction (WAABS) in the 8 locations. The 1st quadrant shows that genotype I070557 was the most unstable and contributed much to the genotype and location interaction. The Njombe environment, which is displayed in that quadrant, had a high discriminative ability for fresh root yield. The 2 nd quadrant includes two genotypes I010040-27 and I011797 which are the most productive but unstable genotypes. The two locations included on that quadrant, Ekona and Bambui, in addition to providing high performance, also provided good discrimination ability for the genotypes. Six genotypes fall in the third quadrant and are considered as low productive genotypes because of the low WAABS values. The Mbalmayo and Meyomessala environments included in this quadrat had 


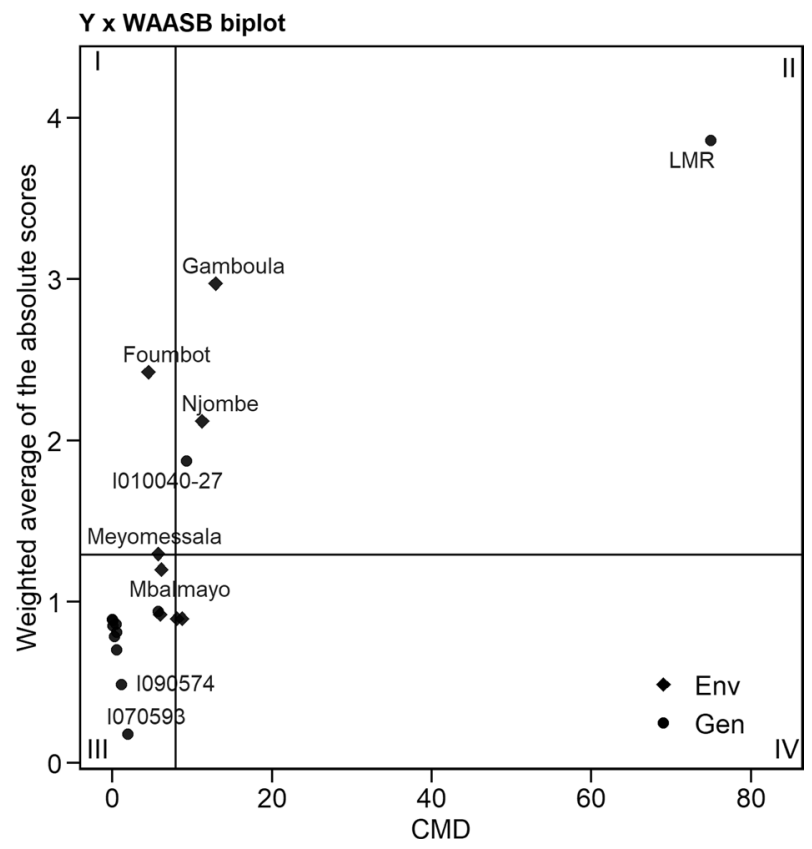

Figure 2. Genotype and genotype by environment interaction (GGE) biplot of the CMD Incidence versus a weighted average of absolute scores for the best linear unbiased predictions of the genotype versus environment interaction (WAASB) of 12 genotypes evaluated in eight environments (combination of 2 cultivation years). ( $R$ V3.6.2, https://cran.r-project.org/web/packages/metan/).

low production and low discrimination ability. Two genotypes I090590 and I071026 were broadly adapted and are displayed in the fourth quadrant. Three locations in this quadrant, Foumbot, Gamboula, and Meiganga, had high yield but with low discriminative ability.

\section{Discussion}

Multi-environment experiments are a primary focus in plant breeding programs; therefore, their prediction accuracy, compared with observed value, is crucial for selection recommendation of cultivars, and the identification of mega-environments. This study showed variable responses of a set of new cassava genotypes for food and nutritional value in contrasting environments in Cameroon, thus justifying the necessity to evaluate genotype by environment interactions. This study, together with the previous study conducted in the same locations, but with different genotypes ${ }^{8}$, provide a highly important set of data on the effects of genotype and environment on 28 cassava genotypes that are in advanced stages of development. Moreover, the two studies together, are a rarity in evaluations that covers a very wide spectrum of pest/disease resistance, yield, and nutritional value, all with a significant potential contribution to food and nutritional security in Central Africa. The four agroecological zones in which the genotypes were tested are representative of the agro-ecologies of the Congo Basin, including nearly all states in Central Africa, except the Sahelian zone ${ }^{33}$. Importantly, we found that the environment was not the main determinant of a genotype response to cassava mosaic virus (CMD) as the heritability was close to one; this opens the possibility of introducing genotypes with good performance in terms of productivity, yield stability, and resistance to pest and disease into areas with similar characteristics as in Cameroon. Indeed, as with varieties for industrial processing, the tested genotypes were initially selected based on their resistance to CMD and yield, as well as provitamin A content for the yellow root genotypes, traits in which variability comes from genetic differences, with very little contribution from environmental factors ${ }^{34}$. We noted, however, two genotypes, I070593 and LMR, that had CMD severity scores of 2.8 and 2.6 respectively on average for both years, although the incidence on the same genotypes was nearly nil (less than $2 \%$ on average). Our two checks, I010040-27 and LMR, displayed on average the same incidence and severity as in the previous study ${ }^{8}$; however, the other improved varieties (10 in total) were five-fold more resistant to CMD compared with the 16 of the previous study, thus confirming the improvement made on the current set of varieties with respect to CMD resistance and the necessity to disseminate those genotypes. The significant interaction observed between environment and genotype for CMD infection could be related to the virus strains present in the locations as previous studies established the presence of various CMD strains in Cameroon, particularly the Ugandan variant which is the most virulent and present in the east region (Gamboula) ${ }^{35}$.

Typical CMD symptoms on cassava plants are misshapen leaves which hamper the growth of the plant and reduce root yields, hence lowering productivity and profitability ${ }^{21,36}$. Contrary to CMD, Cassava Anthracnose Disease (CAD) was found mostly in the forest areas where relative humidity and rainfall significantly influence the levels of CAD inoculum pressure, in addition to favoring the development of its vector Pseudotheraptus devastans Dist (Het. Coreidae) ${ }^{23}$. CAD severity was statistically similar on all genotypes, but with low incidence. Genotype I071026 did not show CAD symptoms during the 2nd year. CAD has become an economic threat to 


\begin{tabular}{|c|c|c|c|c|}
\hline Genotype/statistics & FRY & BY & DM & TCC \\
\hline I070593 & $-0.01 \pm 1.91$ & $-1.68 \pm 1.59^{*}$ & $-4.03 \pm 0.02$ & $+5.04 \pm 0.17^{\star \star}$ \\
\hline I071026 & $+0.29 \pm 1.95$ & $-3.73 \pm 1.62$ & $-2.96 \pm 0.03$ & $+1.95 \pm 0.16^{* *}$ \\
\hline I070557 & $-12.2 \pm 2.23^{\star *}$ & $-0.25 \pm 0.62^{\star *}$ & $-3.19 \pm 0.02$ & $+1.09 \pm 0.17$ \\
\hline I070738 & $-1.87 \pm 1.91$ & $-2.85 \pm 1.59$ & $-4.01 \pm 0.03$ & $+0.43 \pm 0.17^{\star}$ \\
\hline I011797 & $+9.45 \pm 1.91^{\star *}$ & $-2.28 \pm 1.59^{\star}$ & $+0.63 \pm 0.02$ & $-2.06 \pm 0.22^{\star *}$ \\
\hline I010040-27 & $+13.5 \pm 1.89^{* *}$ & $+1.26 \pm 0.57^{\star *}$ & $-1.19 \pm 0.01$ & $-2.56 \pm 0.17^{* *}$ \\
\hline LMR & $-6.78 \pm 0.42$ & $-0.94 \pm 1.63$ & $+9.36 \pm 3.03$ & $-3.90 \pm 0.06$ \\
\hline I090590 & $+5.64 \pm 1.93^{*}$ & $-0.73 \pm 0.59^{*}$ & $-1.08 \pm 0.01$ & - \\
\hline I090537 & $-5.14 \pm 1.99^{\star}$ & $-0.93 \pm 0.65$ & $-0.32 \pm 0.00$ & - \\
\hline I090574 & $-1.70 \pm 1.91$ & $+4.75 \pm 0.22$ & $+3.26 \pm 1.01$ & - \\
\hline I090616 & $-0.57 \pm 1.89$ & $+8.51 \pm 1.57$ & $-0.49 \pm 0.01$ & - \\
\hline I090521 & $-0.54 \pm 1.95$ & $-1.10 \pm 1.62$ & $+3.44 \pm 1.02$ & - \\
\hline Heritability $\left(\mathrm{H}^{2}\right)$ & 0.24 & 0.14 & 0.58 & 0.60 \\
\hline Location variance $(\mathrm{L})$ & $237.4^{*}$ & $113.8^{*}$ & 42.2 & 13.03 \\
\hline Genotype variance $(G)$ & $57.39^{* *}$ & $16.07^{\star *}$ & 0.00 & $723.74^{\star *}$ \\
\hline Gen $\times$ Loc variance & $56.01^{* *}$ & $13.25^{\star *}$ & 0.61 & $28.52^{\star *}$ \\
\hline Residual variance & 124.0 & 84.52 & 9.28 & 38.00 \\
\hline Grand mean & 30.66 & 22.84 & 38.33 & 5.51 \\
\hline SE & 0.79 & 0.57 & 3.85 & 0.06 \\
\hline Minimum & -12.20 & -8.29 & -3.73 & -3.90 \\
\hline Maximum & 13.5 & 10.63 & 8.51 & 5.04 \\
\hline $\mathrm{SD}$ & 16.54 & 11.94 & 35.66 & 2.56 \\
\hline $\mathrm{CV}(\%)$ & 54 & 52.33 & 93.56 & 40.76 \\
\hline n Replicates & 3 & 3 & 3 & 3 \\
\hline n Locations & 8 & 8 & 8 & 8 \\
\hline n Genotypes & 12 & 12 & 12 & 6 \\
\hline
\end{tabular}

Table 3. Best linear unbiased predictors (BLUPs) of breeding values with standard errors for fresh root yield (FRY), biomass yield (BY), dry matter (DM), total carotenoid content (TCC) of cassava genotypes across eight locations. ${ }^{\star} P<0.05,{ }^{*} P<0.01$. The statistics listed for every trait are broad-sense heritability, genotype variance, residual variance, grand mean, $\mathrm{SD}=$ Standard Deviation, the coefficient of variation $(\mathrm{CV} \%)$ ), the number of replications (n Replicates). The statistics shown are the estimates derived.

cassava production as severe outbreaks have been reported ${ }^{22}$. Affected plants display necrotic lesions on leaves and stem, reducing planting material availability ${ }^{37}$. Careful selection of clean planting material and good field maintenance (timely weeding and field aeration) could help in reducing CAD pressure in the forest zone where it is most prevalent.

Interestingly, the genotype I090521 did not show any CMD symptoms over the two trial years despite harboring the highest number of whiteflies per plant as previously demonstrated with four genotypes $(01 / 0098$, 01/1086-55, 95/0211, and 98/0581 $)^{8}$; however, the lack of CMD symptoms could mean that whiteflies did not carry enough virus loads to efficiently transmit the virus, as an increase in whitefly numbers can lead to the higher efficiency of CMD transmission on cassava ${ }^{38}$ and also could likely be explained by the resistance mechanism of this cassava line. This contradicts other findings ${ }^{39}$ which reported that 10 whiteflies per plant constituted an adequate population for the spread of CMD due to their persistent mode of transmission.

The observed resistance to major disease was translated into a higher yield for the improved genotypes. These varieties could also be carriers of genes for higher yield. Current cassava production in Cameroon (and in the Central Africa region respectively) stands at 5,798,909 tons (resp. 52,019,756 tons) with an average yield of 14.5 $\mathrm{t} / \mathrm{ha}$ (resp. $8.9 \mathrm{t} / \mathrm{ha})^{3}$. Therefore, promoting the new genotypes with an average yield of $31 \mathrm{t} / \mathrm{ha}$ could potentially increase production in Cameroon to $12,353,035$ tons with the current production areas $(398,485$ ha) which would represent an increase from 11 to $24 \%$ of the cassava production in Central Africa. It is worth noting the sharp increase in yield of the check I010040-27 which almost doubled within two years after its first evaluation. Cassava's potential to alleviate food and nutritional security in Central Africa would substantially increase if neighboring countries sharing similar ecologies with Cameroon (Gabon, Equatorial Guinea, Central African Republic, Congo) - where cassava is an essential food security crop-also adopt the new genotypes.

Two genotypes (I090590, and I0701026) produced the highest and most stable fresh root yield across locations, which are qualities that favors them for dissemination throughout the targeted environments to improve cassava yields and hence food security. Overall, tested cassava genotypes performed best at Ekona and Bambui, probably because of the high $\mathrm{K}$ and Organic $\mathrm{C}$ in their soils ${ }^{40}$. Dry matter content was constant for all genotypes across all environments. As a polygenic trait, dry matter varies from one genotype to another (20-40\%) and is usually stable across locations ${ }^{41}$. Genotypes with high dry matter $(>30 \%)$ are generally mealy with high starch 

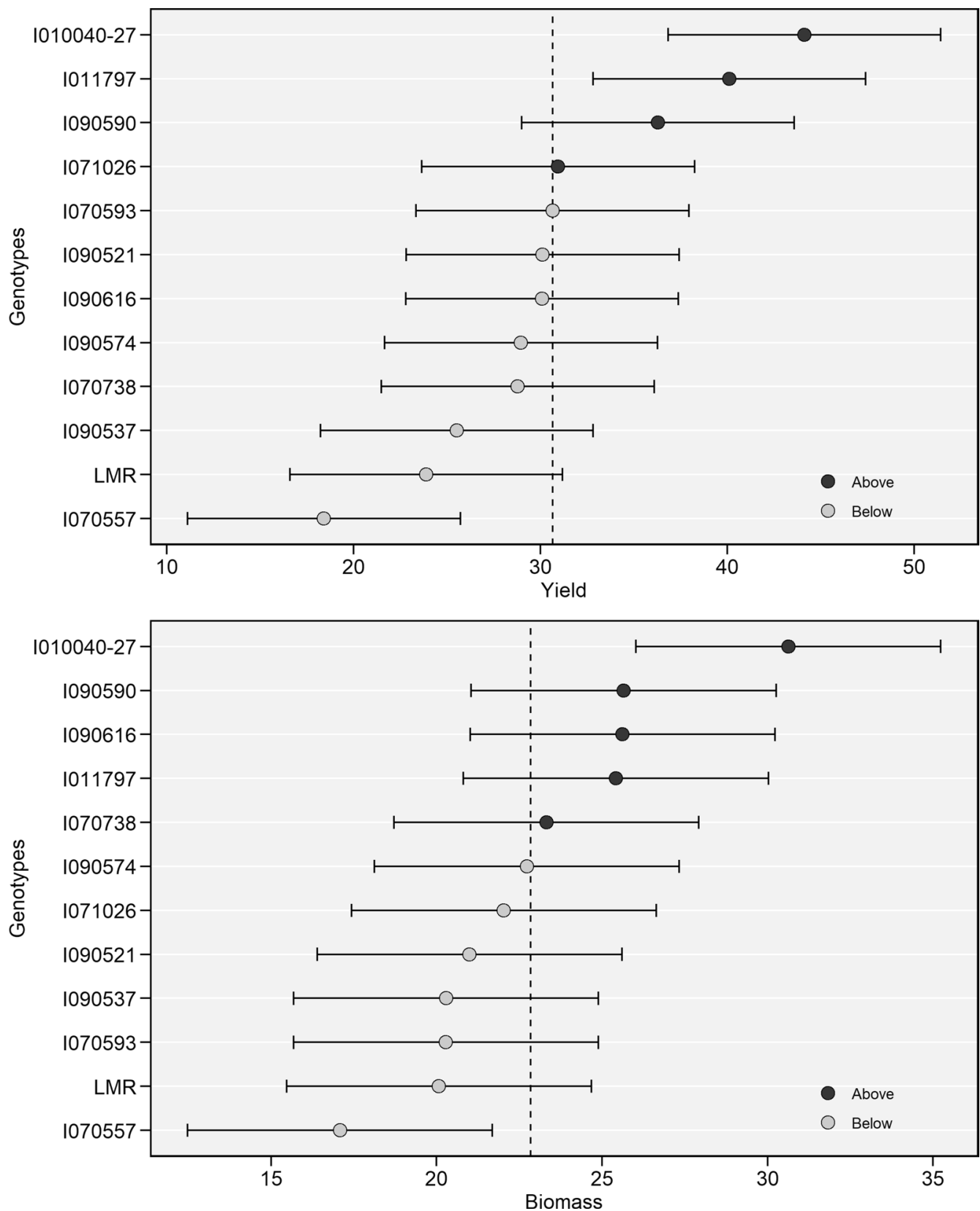

Figure 3. Best linear unbiased prediction for biomass (A) and fresh root yield (B) for 12 genotypes. Black and grey circles represent the genotypes that had BLUP above and below of BLUP mean, respectively. Horizontal error bars represent the $95 \%$ confidence interval of a prediction considering a two-tailed $t$ test. (R V3.6.2, https://cran.r-project.org/web/packages/metan/).

content ${ }^{42-44}$, making them suitable for processing into flour and starch which have been shown to improve the potential for cassava adoption and commercialization for income generation and livelihoods improvement ${ }^{15,45}$.

Nutritionally-biofortified genotypes evaluated in this study contain up to 6-folds higher provitamin A $\beta$-carotene compared with the local genotype, underlining the potential contribution of the biofortified genotypes to nutritional security in Cameroon and central Africa. These varieties have almost 3 times (up to $11.1 \mu \mathrm{g} / \mathrm{g}$ ) the level of carotenoids contents of our previous set of yellow varieties ${ }^{8}$, thus justifying the improvement of their nutritional content and the need to promote them for nutritional security in central Africa. Total carotenoid content is known to be affected by the location in which the genotype is grown, especially in sweet potato (Ipomoea batatas (L. $)^{46}$, but it appears not to be the case for cassava as the levels of provitamin A ( $\beta$-carotene) of a genotype were stable across all the different environments used in the present study and elsewhere ${ }^{47}$. These results are very encouraging, but it would be necessary to conserve as much of the provitamin A as possible when cassava is transformed into different products-including cooking-to harness the full potential of biofortified cassava's contribution to reductions in vitamin A deficiency ${ }^{48}$. 


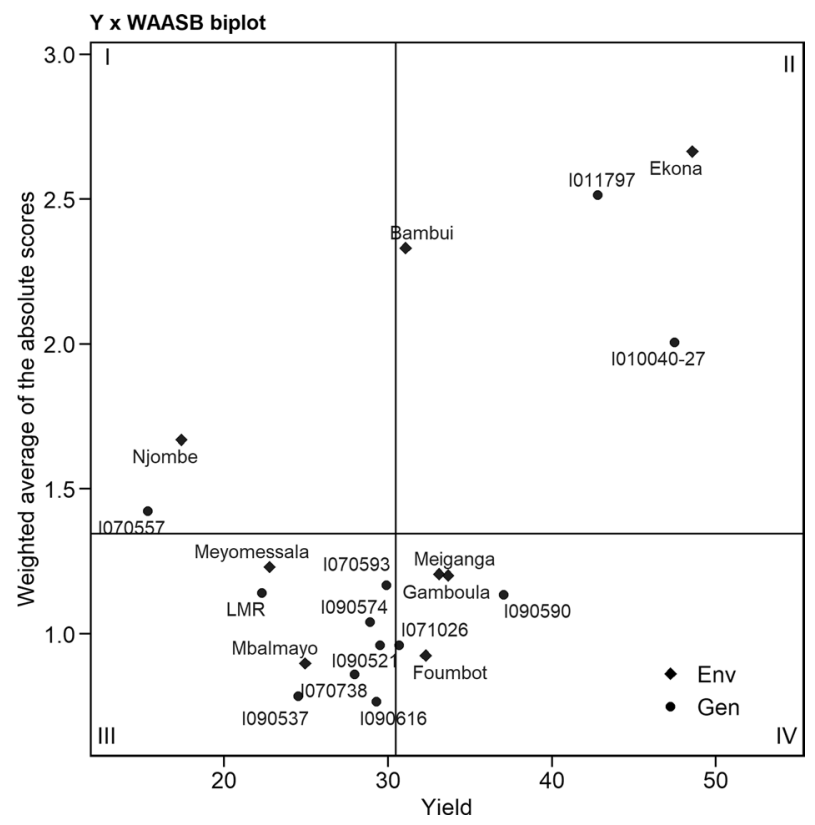

Figure 4. Biplot of the fresh root yield versus a weighted average of absolute scores for the best linear unbiased prediction s of the genotype versus environment interaction (WAASB) of 12 genotypes evaluated in eight environments. A hypothetical highly productive and broadly adapted genotype is depicted by a black circle. ( $R$ V3.6.2, https://cran.r-project.org/web/packages/metan/).

\begin{tabular}{|l|l|l|l|}
\hline Accession & Cassava base name & Pedigree & Flesh color \\
\hline I070593 & IITA-TMS-IBA070593 & IITA-TMS-IBA011277/IITA-TMS-IBA990067 & Yellow \\
\hline I010040-27 & IITA-TMS-IBA010040 & IITA-TMS-IBA010040/?* & Yellow \\
\hline I011797 & IITA-TMS-IBA011797 & IITA-TMS-IBA950379/TMEB117 & Yellow \\
\hline I070557 & IITA-TMS-IBA070557 & IITA-TMS-IBA011663/IITA-TMS-IBA940330 & Yellow \\
\hline I070738 & IITA-TMS-IBA070738 & IITA-TMS-IBA011649/IITA-TMS-IBA051237 & Yellow \\
\hline I071026 & IITA-TMS-IBA071026 & IITA-TMS-IBA011277/IITA-TMS-IBA011412 (4X) & Yellow \\
\hline I090521 & IITA-TMS-IBA090521 & IITA-TMS-IBA974763/MAUNJILI & White \\
\hline I090537 & IITA-TMS-IBA090537 & IITA-TMS-IBA961569/IITA-TMS-IBA961569 & White \\
\hline I090574 & IITA-TMS-IBA090574 & IITA-TMS-IBA961632/CM5306-8 & White \\
\hline I090590 & IITA-TMS-IBA090590 & IITA-TMS-IBA972205/MCOL 1468 & White \\
\hline I090616 & IITA-TMS-IBA090616 & IITA-TMS-MOK980068/CM6921-3 & White \\
\hline LMR & LMR & NA/NA & White \\
\hline
\end{tabular}

Table 4. Cassava genotypes used in the trial. ${ }^{\star} /$ ? Denote half sibling.

\section{Conclusion}

This study identified high-yielding cassava genotypes with higher levels of resistance/tolerance to pests and diseases and with elevated provitamin A-improved nutritional content. Disseminating the selected genotypes for cassava production in Cameroon-and by extension elsewhere in Central Africa-would improve cassava production for food and nutritional security. Despite the good performance of most of the tested genotypes, there is also a strong need to conduct consumer preference studies to match the usability of these newly developed varieties to actual use of cassava in the area of introduction to ensure proper adoption by the end-users in the various agro-ecologies.

\section{Materials and methods}

Cassava genotypes. IITA had the permission to collect all the plants used in this study. The improved cassava genotypes used were selected in Nigeria by the IITA cassava breeding unit and sent to IITA Cameroon. Accession names and their pedigree are available in the cassava database (Table 4) (www.cassavabase.org). All improved genotypes were tested along with two cassava genotypes from our recent work ${ }^{8}$ which were used here as references (1) for high yield (I010040-27) and (2) for high susceptibility to cassava mosaic virus disease (LMR). Including reference genotypes is a common practice in such studies. The present and previous ${ }^{8}$ study were conducted in the same locations (not same fields) in Cameroon and followed a similar methodology to 


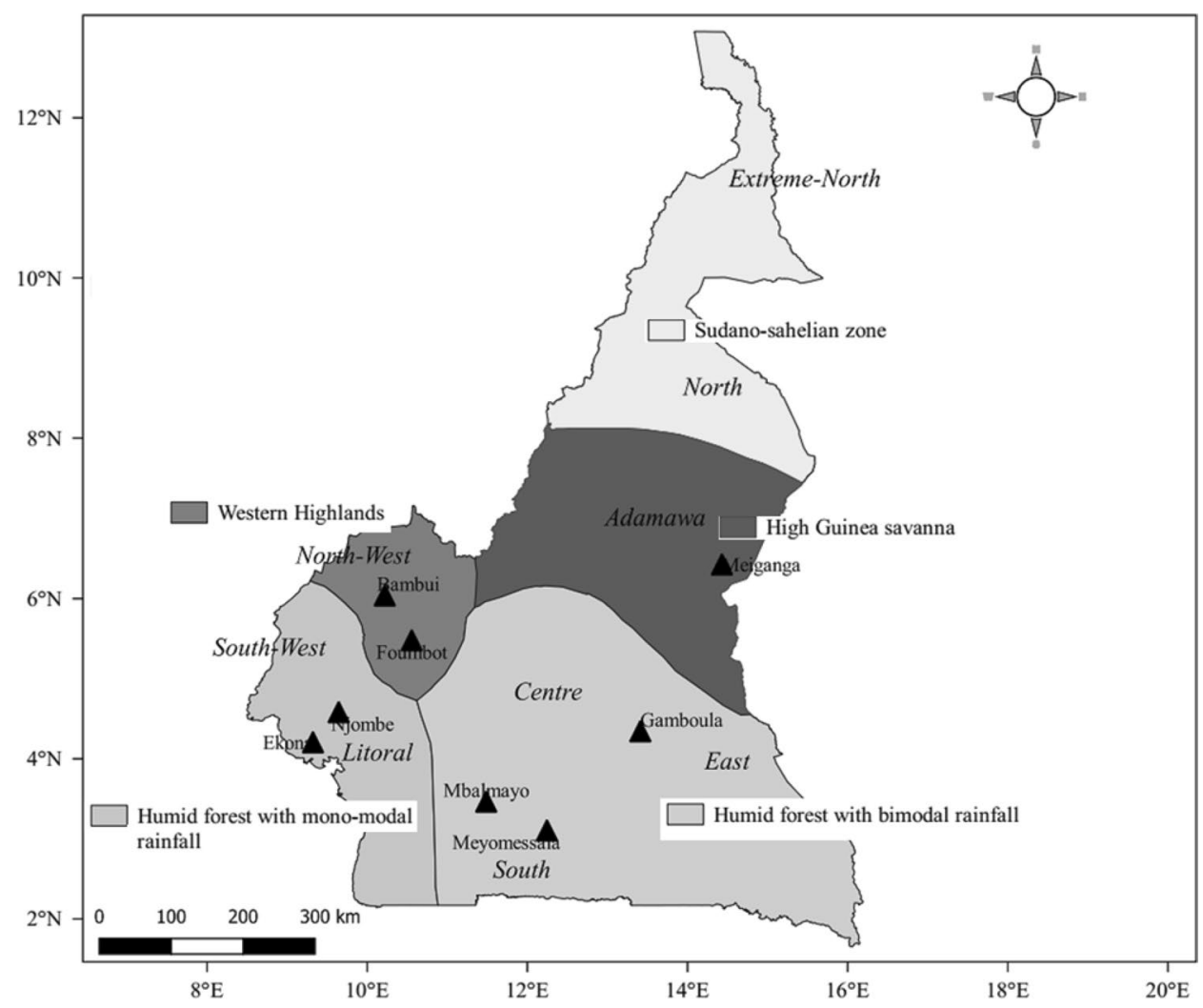

Figure 5. Locations of the cassava multilocation trial (Arcgis V10.3.1, https://desktop.arcgis.com/en/arcmap/).

provide a basis for comparisons between them. The first study ${ }^{8}$ used mostly white-fleshed genotypes oriented toward industrial processing, while the second (present) study emphasized a new set of white-fleshed genotypes for boiling and yellow-fleshed genotypes with higher total carotenoids content. The studies complied with the local and national regulations in Cameroon.

Trial locations and characteristics. Field trials were established in eight locations during the 2016/2017 and 2017/2018 first cropping season that typically starts in March of each year. These locations are grouped into 4 agroecological zones as classified by the Institute Agronomic Research for Development of Cameroon (IRAD). The locations of Mbalmayo, Meyomessala, and Gamboula are in the humid forest zone which is characterized by a bimodal rainfall pattern, while the locations of Njombe and Ekona are in the humid forest with monomodal rainfall patterns. The locations of Foumbot and Bambui are in the Western Highlands while Meiganga is in the high Guinean savannah (Fig. 5). Vegetation in these locations as representative of the land cover of other countries of Central Africa ${ }^{33}$.

Trial set-up and monitoring. The trial was set-up in a completely randomized block design with three replicate blocks comprised of $5 \times 6 \mathrm{~m}$ plots of 42 plants (with $1 \mathrm{~m}$ spacing between and within rows) of each of the 12 genotypes. Plants were grown under rainfed conditions for 12 months and managed according to prevailing farmer practices. Pesticides and fertilizers were not used at any time during the trials. Plots were manually weeded with machete and hoe as needed.

Soil sampling. At each location, 5 soil samples were collected from each plot and mixed thoroughly in a plastic basin to obtain a composite soil sample. A subsample of $250 \mathrm{~g}$ of soil from each plot was used for the determination of various soil physical and chemical properties at the IITA-Cameroon Analytical Laboratory. Soil samples were air-dried and ground to pass through a 2-mm sieve. The sample was further ground to pass through a $0.5 \mathrm{~mm}$ sieve for $\mathrm{C}$ and $\mathrm{N}$ analysis. Soil $\mathrm{pH}$ in water was determined in a 1:2.5 (w/v) soil: water suspension. Organic $\mathrm{C}$ was determined by chromic acid digestion and spectrophotometric analysis ${ }^{49}$. Total $\mathrm{N}$ was determined from a wet acid digest ${ }^{50}$ and analyzed by colorimetric analysis. Exchangeable $\mathrm{Ca}, \mathrm{Mg}, \mathrm{K}$, and $\mathrm{P}$ were extracted using the Mehlich-3 procedure ${ }^{51}$, and the cations were determined by flame atomic absorption spectrophotometry. Exchangeable P from the resulting extract above was determined with the molybdate blue procedure $^{52}$. Particle size was determined with a hydrometer.

Pests and diseases assessment. Cassava disease incidence and severity were evaluated at 3, 6, and 9 months after planting on 10 plants per plot, excluding border rows, while alternating plants within a row. On 
each plant, the number of whitefly adults (Bemisia tabaci Gennadius) was counted on the top (the first five apical leaves of the plant tilting the apex) of the plant, while the number of nymphs was counted on the 14th fully developed leaf ${ }^{53}$. The cassava green mite (CGM) was counted on the fifth fully developed leaf using a head lens (OptiVISOR Optical Glass Binocular Magnifier, 10×). CMD incidence (presence/absence) was scored on the whole plant foliage, while CAD incidence and severity were scored based on disease symptoms on the stems. Disease and damage scoring was done on a scale of 1 (no symptoms observed) to 5 (severe symptoms on plant parts) ${ }^{54}$.

At harvest (12 months after planting), above-ground biomass (stems and leaves) and storage roots were weighed using Macro scales type with optional accessories (Macro-Line 800050, PRESOLA). Samples of $500 \mathrm{~g}$ of the fresh root of each genotype were collected and oven-dried at $60{ }^{\circ} \mathrm{C}$ for $48 \mathrm{~h}$ to measure their dry matter content. Total carotenoid content (TCC) in storage roots was determined within $24 \mathrm{~h}$ of harvest using iCheck Carotene following the BioAnalyt protocol ${ }^{53}$. Only yellow flesh genotypes were considered for the carotenoids content analysis as the yellow coloration of the parenchyma is closely related to carotenoid content ${ }^{55}$. The local landrace LMR was included as a check.

Statistical analysis. Incidence data was calculated for CMD and CAD for each plot by calculating the percentage of sampled plants that showed symptoms of the diseases.

We used the metan package of the R 3.6.2 software ${ }^{56}$ to perform a stability analysis of multi-environment trial data $\left(\right.$ MET $\left.^{57}\right)$ using parametric and non-parametric. MET allows the identification of genotypes that display a small temporal variability - which is desired by breeders and is beneficial to growers, or cultivars that are consistent from location to location - which is desired by and is beneficial to seed companies and breeders ${ }^{57}$. Incidence data were calculated for CMD and CAD by calculating the percentage of sampled plants that showed symptoms of the diseases. Whitefly and CGM densities were log-transformed to reduce heteroscedasticity inherent in insect and mite counts. The best linear unbiased prediction (BLUP) was used to predict Breeding Values (BV) of each genotype for cassava mosaic disease incidence and severity, cassava anthracnose disease incidence and severity, whitefly and cassava green mite densities, fresh root yield (FRY), biomass (BY), dry matter (DM), total carotenoid content (TCC), CMD and CAD severity. The BLUP was performed using the linear mixed model's approach (ANOVA) that considered cassava genotype as fixed factor and locations and year as random factors. The model also included genotype by location $(\mathrm{G} \times \mathrm{L})$ interactions.

To select genotypes that combine high performance and stability, we introduced the weighted average of absolute scores from the singular value decomposition of the matrix of best linear unbiased predictions for the genotype $\times$ environment interaction effects generated by a linear mixed effect model index (WAASB), which is a superiority index that allows weighting between performance (in our study, fresh root yield and CMD incidence) and stability (WAASB index). The first step is rescaling FRY and WAASB; CMD and WAASB that can be directly used to compare genotypes. The best values for FRY and CMD are the highest value and for WAASB is the lowest value ${ }^{58-60}$.

\section{Data availability}

The datasets generated during and/or analyzed during the current study are available from the corresponding author on reasonable request.

Received: 13 October 2020; Accepted: 22 March 2021

Published online: 01 April 2021

\section{References}

1. FAO. Save and grow cassava. FAO, Rome (2013).

2. Tufan, H. A. Next-generation cassava breeding project [WWW Document]. (accessed 31 March 15, 2013) http://www.nextgencas sava.org/about.html.

3. FAO. Online statistical database: Food balance. FAOSTAT. [2018-12- 02]. (accessed 18 July 2018) http://faostat3.fao.org/downl oad/FB/*/E. www.fao.org/faostat/en/.

4. Thresh, J. M. \& Cooter, R. J. Strategies for controlling cassava mosaic virus disease in Africa. Plant Pathol. 54, 587-614. https:// doi.org/10.1111/j.1365-3059.2005.01282x (2005).

5. Legg, J. P., Owor, B., Sseruwagi, P. \& Ndunguru, J. Cassava mosaic virus disease in east and central Africa: epidemiology and management of a regional pandemic. Adv. Virus Res. 67, 355-418 (2006).

6. Bisimwa, E., Walangululu, J. \& Bragard, C. Cassava mosaic disease yield loss assessment under various altitude agroecosystems in the SudKivu Region, Democratic Republic of Congo. Tropicul 33, 101-110 (2015).

7. Spencer, D. S. C. \& Ezedinma, C. Cassava cultivation in sub-Saharan Africa. In Achieving Sustainable Cultivation of Cassava (ed. Hershey, C.) 123-148 (Burleigh Dodds Science Publishing Limited, 2017).

8. Fotso, A. K. et al. AMMI analysis of cassava response to contrasting environments: case study of genotype by environment effect on pests and diseases, root yield, and carotenoids content in Cameroon. Euphyti. 214(9), 155-167. https://doi.org/10.1007/s10681018-2234-z (2018).

9. Muthayya, S. et al. The global hidden hunger indices and maps: an advocacy tool for action. PLoS ONE 8, e67860. https://doi.org/ 10.1371/journal.pone.0067860 (2013).

10. WFP. Cameroon country brief, February 2018 (2018).

11. Prudencio, Y. C. \& Al-Hassan, R. The food security stabilization roles of cassava in Africa. Food Policy 19, 57-64. https://doi.org/ 10.1016/0306-9192(94)90008-6 (1994).

12. Fischer, T., Byerlee, D. \& Edmeades, G. Australian Centre for International Agricultural Research. Crop yields and global food security: will yield increase continue to feed the world? ACIAR Monograph No. 158. Australian Centre for International Agricultural Research (2014).

13. Onodu, B. \& Culas, R. The role of Cassava production in improving food security in the delta state of Nigeria. 1-34 (2017).

14. Waisundara, V. Y. Introductory chapter: cassava as a staple food. In: Cassava. InTech (2018). 
15. Benesi, I., Labuschagne, M., Dixon, A. \& Mahungu, N. Genotype x environment interaction effects on native cassava starch quality and potential for starch use in the commercial sector. African Crop Sci J. 12, 205-216. https://doi.org/10.4314/acsj.v12i3.27880 (2005).

16. AIEA. Cassava production guidelines for food security and adaptation to climate change in Asia and Africa. InternationalAtomic Energy Agency, Vienna (2018).

17. Ajayi, C. O. \& Olutumise, A. I. Determinants of food security and technical efficiency of cassava farmers in Ondo State Nigeria. Int Food Agribus Manag Rev. 21, 915-928. https://doi.org/10.22434/IFAMR2016.0151 (2018).

18. Reincke, K. et al. Key factors influencing food security of smallholder farmers in Tanzania and the role of cassava as a strategic crop. Food Secur. 10, 911-924. https://doi.org/10.1007/s12571-018-0814-3 (2018).

19. El-Sharkawy, M. A. Cassava biology and physiology. Plant. Mol. Biol. 53, 621-641. https://doi.org/10.1023/B:PLAN.0000019109. 01740.c6 (2003)

20. Fokunang, C. N., Ikotun, T., Dixon, A. G. O. \& Akem, C. N. First report of Colletotrichum gloeosporioides f. sp. manihotis, cause of cassava anthracnose disease, being seed-borne and seed-transmitted in cassava. Plant Dis. 81, 695-695. https://doi.org/10.1094/ PDIS.1997.81.6.695C (1997).

21. Thresh, J. M. Impact of plant virus disease in developping countries. In Virus and Virus-Like Diseases of Major Crops in Developing Countries (eds Loebenstein, G. \& Thottappilly, G.) 1-30 (Springer, 2003).

22. William, M. N. M., Mbega, E. R. \& Mabagala, R. B. An outbreak of anthracnose caused by Colletotrichum gloesporioides f.sp. manihotis in cassava in North Western Tanzania (2012).

23. Liu, X. et al. Colletotrichum species associated with cassava anthracnose in China. J. Phytopathol. 167, 1-9. https://doi.org/10.1111/ jph.12765 (2019).

24. Chikoti, R., Mulenga, R., Tembo, M. \& Sseruwagi, P. Cassava mosaic disease: a review of a threat to cassava production in Zambia. J. Plant. Pathol. 101, 467-477. https://doi.org/10.1007/s42161-019-00255-0 (2019).

25. Bouis, H. E. Plant breeding: a new tool for fighting micronutrient malnutrition. J. Nutr. 132, 491S-494S. https://doi.org/10.1093/ jn/132.3.491s (2002)

26. Beyer, P. Golden Rice and "Golden" crops for human nutrition. N. Biotechnol. 27, 478-481 (2010).

27. Adenle, A. A., Aworh, O. C., Akromah, R. \& Parayil, G. Developing GM super cassava for improved health and food security: future challenges in Africa. Agric. Food Secur. 1, 11. https://doi.org/10.1186/2048-7010-1-1116 (2012).

28. Kawano, K., Fukuda, W. M. G. \& Cenpukdee, U. Genetic and environmental effects on dry matter content of cassava root. Crop Sci. 27, 69. https://doi.org/10.2135/cropsci1987.0011183x002700010018x (1987).

29. Kawano, K. Thirty years of cassava breeding for productivity - Biological and social factors for success. Crop Sci. 43, 1325-1335. https://doi.org/10.2135/cropsci2003.1325 (2003).

30. Crow, G. H. Multi-environment experiments in agriculture. 1-48 (2010).

31. Nassir, A. L. \& Ariyo, O. J. Genotype $x$ environment interaction and yield-stability analyses of rice grown in tropical Inland Swamp. Not Bot Hort Agrobot Cluj. 39, 220-225 (2011).

32. Pariyo, A. et al. Stability of resistance to cassava brown streak disease in major agro-ecologies of Uganda. J. Plant Breed Crop Sci. 7, 67-78. https://doi.org/10.5897/JPBCS2013.0490 (2015).

33. Robiglio, V. \& Sinclair, F. Maintaining the conservation value of shifting cultivation landscapes requires spatially explicit interventions. Environ. Manage. 48, 289-306. https://doi.org/10.1007/s00267-010-9611-2 (2011).

34. Pacheco, Á., Vargas, M. \& Alvarado G. et al. GEA-R (Genotype $\mathrm{x}$ environment analysis with $\mathrm{r}$ for windows) Version 3.0: CIMMYT Research Software Data verse: CIMMYT Data verse Network (2015).

35. Akinbade, S. et al. First report of the East African cassava mosaic virus-Uganda (EACMV-UG) infecting cassava (Manihot esculenta) in Cameroon. New Dis. Rep. 21, 22 (2010).

36. Samura, A. E. et al. Effect of cassava mosaic disease (CMD) on yield and profitability of cassava and gari production enterprises in Sierra Leone. J. Agric. Sci. 9, 205. https://doi.org/10.5539/jas.v9n2p205 (2017).

37. Owolade, O. F. Line x tester analysis for resistance to cassava anthracnose disease. World J. Agric. Sci. 2, 109-114 (2006).

38. Njoroge, M. K., Mutisya, D. L., Miano, D. W. \& Kilalo, D. C. Whiteflies species distribution and abundance on cassava crop in different agro-ecological zones of Kenya. J. Entomol. Zool. Stud. 258, 258-262 (2016).

39. Legg, J. P. et al. Comparing the regional epidemiology of the cassava mosaic and cassava brown streak virus pandemics in Africa. Virus Res. 159, 161-170 (2011).

40. Kota, S. et al. Genotype x environment interaction analysis for grain yield in new plant type (NPT) wheat derivatives SABRAO. J. Breed Genet. 45, 382-390 (2013).

41. Braima, J. et al. Pest control in cassava farms: IPM field guide for extension agent (Wordsmiths Printers, 2000).

42. Perez, R. D. V. \& Villamayor, F. G. J. Relationships among specific gravity, dry matter and starch contents of cassava roots NSTA. Natl. Sci. Technol. Author. J. 9, 18-22 (1984).

43. Safo-Kantanka, O. \& Owusu-Nipah, J. Cassava varietal screening for cooking quality: relationship between dry matter, starch content, mealiness and certain microscopic observations of the raw and cooked tuber. J. Sci. Food Agric. 60, 99-104. https://doi. org/10.1002/jsfa.2740600116 (1992).

44. Ebah-Djedji, B. C. et al. Effect of harvest period on starch yield and dry matter content from the tuberous roots of improved cassava (Manihot esculenta Crantz) varieties. Pak. J. Nutr. 11, 414-418. https://doi.org/10.3923/pin.2012.414.418 (2012).

45. Mtunguja, M. K. et al. Effect of genotype and genotype by environment interaction on total cyanide content, fresh root, and starch yield in farmer-preferred cassava landraces in Tanzania. Food Sci. Nutr. 4, 791-801. https://doi.org/10.1002/fsn3.345 (2016).

46. Manrique, K. \& Hermann, M. CIP program report effect of GxE Interaction on root yield and beta- carotene content of selected sweet potato (Ipomoea batatas (L) Lam.) varieties and breeding clones (2000).

47. Nduwumuremyi, A., Melis, R., Shanahan, P. \& Asiimwe, T. Interaction of genotype and environment effects on important traits of cassava (Manihot esculenta Crantz). Crop J. 5, 373-386. https://doi.org/10.1016/j.cj.2017.02.004 (2017).

48. Eyinla, T., Mazilla-Dixon, B., Alamu, O. E. \& Sausi, R. A. Retention of Pro-Vitamin A content in products from new biofortified cassava varieties. Foods. 8, 14 (2019).

49. Heanes, D. L. Determination of total organic-c in soils by an improved chromic acid digestion and spectrophotometric procedure. Commun. Soil Sci. Plant Anal. 15, 1191-1213. https://doi.org/10.1080/00103628409367551 (1984).

50. Buondonno, A., Rashad, A. A. \& Coppola, E. Comparing tests for soil fertility: the hydrogen peroxide/sulfuric acid treatment as an alternative to the copper/selenium catalyzed digestion process for routine determination of soil nitrogen-kjeldahl. Commun. Soil Sci. Plant Anal. 26, 1607-1619. https://doi.org/10.1080/00103629509369394 (1995).

51. Mehlich, A. \& Mehlich, B. Soil test extractant: a modification of Mehlich 2 extractant. Commun. Soil Sci. Plant Anal. 15, 1409-1416. https://doi.org/10.1080/00103628409367568 (1984).

52. Murphy, J. \& Riley, J. P. A modified single solution method for the determination of phosphate in natural waters. Anal Chim. Acta. 27, 31-36. https://doi.org/10.1016/S0003-2670(00)88444-5 (1962).

53. IITA. Cassava in tropical Africa: a reference manual. Ibadan, Nigeria (1990).

54. Kulakow, P. A. et al. Linearity, reproducibility and comparison of iCheck carotene with Spectrophotometer and HPLC for evaluation of total carotenoids in cassava roots. Eur. J. Nutr. Food Saf. 5(5), 1040-1041. https://doi.org/10.13140/2.1.4534.4007 (2015).

55. Ceballos, H. et al. Carotenoids in Cassava Roots. In Carotenoids (eds Cvetkovic, R. G. \& Goran, S. N.) 189-221 (Intech, 2017). 
56. R Core Team. R: A language and environment for statistical computing. R Foundation for Statistical Computing, Vienna, Austria. URL http://www.R-project.org/ (2018).

57. Olivoto, T. \& Lucio, A. D. metan: an R package for multi-environment trial analysis. Methods Ecol. Evol. 11(6), 783-789. https:// doi.org/10.1111/2041-210X.13384 (2020).

58. Yan, W. \& Kang, M. S. GGE biplot analysis: a graphical tool for breeders, geneticists, and agronomists. Google Search (2003).

59. Yan, W. \& Tinker, N. A. Biplot analysis of multi-environment trial data: principles and applications. Can J Plant Sci. 86, 623-645. https://doi.org/10.4141/P05-169 (2006).

60. Olivoto, T., Lucio, A. D. C., da Silva, J. A. G., Marchioro, V. S. \& de Souxa, V. Q. Mean performance oand stability in Multienviroenement trial I: combining features of AMMI and BLUP techniques I. Agron. J. 111, 29499-32960. https://doi.org/10.2134/agron j2019.03.0220 (2019).

\section{Acknowledgements}

This work was supported by the Agricultural Investment and Market Development Project jointly funded by the Cameroon government, Japan Policy, the World Bank, and Consultative Group on International Agricultural Research Program on Roots, Tubers, and Bananas.

\section{Author contributions}

Conceptualization: R.H., A.K.F., E.N.N., and K.K.M.F.; Experimental work: I.T. and A.K.F.; Data analysis and interpretation: A.K.F. and I.T.; Supervision: E.N.N., C.M., K.K.M.F., R.H., and A.K.F.; Visualization: F.N.A., C.S., V.W.L., I.N., G.M., E.P., P.K., and C.K.; Writing—original draft: A.K.F., I.T. and R.H.; Writing—review manuscript content \& editing: R.H. and K.K.M.F. All authors reviewed and approved the final manuscript.

\section{Competing interests}

The authors declare no competing interests.

\section{Additional information}

Correspondence and requests for materials should be addressed to A.K.F.

Reprints and permissions information is available at www.nature.com/reprints.

Publisher's note Springer Nature remains neutral with regard to jurisdictional claims in published maps and institutional affiliations.

Open Access This article is licensed under a Creative Commons Attribution 4.0 International License, which permits use, sharing, adaptation, distribution and reproduction in any medium or format, as long as you give appropriate credit to the original author(s) and the source, provide a link to the Creative Commons licence, and indicate if changes were made. The images or other third party material in this article are included in the article's Creative Commons licence, unless indicated otherwise in a credit line to the material. If material is not included in the article's Creative Commons licence and your intended use is not permitted by statutory regulation or exceeds the permitted use, you will need to obtain permission directly from the copyright holder. To view a copy of this licence, visit http://creativecommons.org/licenses/by/4.0/.

(C) The Author(s) 2021 